\section{Microfinance Activities and Factors Affecting the Growth of Microfinance in Developed \& Developing Countries}

\author{
Muhammad Sajid Saeed \\ Glasgow Caledonian University \\ United Kingdom \\ E-mail: MSAEED14@caledonian.ac.uk
}

Received: February 24, 2014 Accepted: April 11, 2014 Published: April 20, 2014

doi:10.5296/ifb.v1i1.5473 URL: http://dx.doi.org/10.5296/ifb.v1i1.5473

\begin{abstract}
Microfinance Institutions (MFIs) have served millions of poor people around the world by offering them small loans with easy repayment terms. This review paper highlights the microfinance activities performed by the MFIs and also indicates the critical factors that hinder the growth of microfinance in developing and developed nations. It is found that the foremost factors obstructing the adoption of microfinance are: lack of financial stability, uncontrolled growth, cultural and value impede, systematic frauds, bureaucratic obstacles, state intervention, methodological defects, and shortage of credit rating agencies.
\end{abstract}

Keywords: Microfinance, growth of microfinance, Microfinance obstructing factors 


\section{MIN Macrothink}

\section{Introduction and Background}

According to Consultative Group to Assist Poor (CGAP), "microfinance offers poor people to access basic financial services" (Fardoust et al. 2010: 478). The idea of microfinance was originally developed by Muhammad Yunus when he founded the Grameen Bank in 1976 in Bangladesh. The bank was established in effect of several small projects of NGOs that were providing credits to poor people. In the early days of establishment, Grameen bank emphasised on small loans and savings and put interest rates adequately high to cover expenditures. The bank asked borrowers to organise a group of five people and arrange weekly meeting with each other to repay their finances and share valuable thoughts and opinions. In the early 1990s, the idea of microfinance started to become popular among commercial banks, and many powerful banks and financial institutions adopted microfinance (Otero 1999). In 2005, microfinance concept inspired many big financial institutions worldwide and Muhammad Yunus received a Nobel Prize in 2006 for his innovative idea (King 2012). By looking at the successful experiment and great achievement, Yunus decided to expand the network of Grameen bank in other parts of the world. In 2011, Grameen bank had nearly 2,565 branches in 81,379 villages worldwide and served over 3,500,000 poor people with the help of 22,124 staff members (Grameen Bank 2011).

Microfinance as a new strategy, and with a complete faith in the financial system market and theory, worked like a 'magic bullet' against poverty. In the opinion of several experts and theorists, microfinance helped many developing economies to generate profits as well as reduce poverty at one fell swoop (Tulchin 2003). Microfinance has deep roots in developing countries especially in Asia. Regardless of its popularity in developing countries, this practice was also informally adopted by many European countries during the 1980s and 1990s. The informal practice and self-help created the need for Microfinance Institutions (MFIs) in Europe as well. For example, Ireland's early history of microfinance can be traced back in the 1980s when self-help led to financial advancement, conductive regulations, legal backing, and mass microfinance movement (Khan and Rahaman 2007). The Irish loan funds introduced by charity organisations in the beginning of the eighteenth century. However, some objectionable laws and regulations imposed by the commercial banks brought it down (Khan and Rahaman 2007).

In Germany, rural finance was introduced in the early 1960s when Friendrich Wilhelm Raiffeisen developed a scheme for microfinance (Steinwand 2001). This scheme was named 'credit cooperative' and originally used to provide financing to poor farmers in rural areas. By 1910, nearly 1.4 million farmers gained countless benefits from this scheme. Later on, the scheme was introduced in Northern Italy and Ireland to serve needy farmers (Morduch 1999). Similarly, during the 1970s, British and Dutch set up a microfinance based model namely 'Raiffeisen Model' when they were ruling Indonesia and India. Today an Indonesian bank, the Bank of Rakyat (BRI) is a thriving MFI which is based on the idea of Raiffeisen Model (Seibel 2005). In fact, the microfinance concept is popular everywhere in the world but it has different names in different countries. For instance, in China it is called 'Hui'; in India it is known as 'Chit funds'; and in Philippines its name is 'Paluwagan' (Seibel 2005). 


\section{MInstitute Macrothink}

\section{Objective}

The objective of this paper is twofold. First, to recall the microfinance activities performed by the MFIs and secondly, to fill the literature gap by highlighting the factors that hinder the growth of microfinance systems and institutions in both developing and developed countries.

\section{Methodology}

The nature of this study is flexible and discrete in exploring the issues that obstruct the implementation and growth of MFIs in developed and developing economies. Therefore, the researcher has chosen exploratory research design to effectively and openly address research objectives. This paper considers meaningful qualitative information which is collected from a range of secondary sources including journals, books, newspapers, reports, databases and libraries. The digital 'snowballing' approach is employed to acquire information from most latest and pertinent sources (Bryman 2008). During digital snowballing, the researcher extended the search throughout different databases and libraries such as EBSCO Host, science direct, Safari books, Google scholar, Taylor and Francis, IEEE Xplore and Google books. The keywords used to obtain detailed information include: microfinance, microfinance in developing and developed countries, growth of microfinance, microfinance obstructing factors, role of microfinance, microfinance activities and so forth.

\section{Global Perception of Microfinance}

Microfinance has a worldwide impression as a successful tool for reducing poverty. Several policy makers around the world attempted to investigate the availability and sustainability of microfinance for poor people in the past. The investors, donors, and other key stakeholders of the microfinance claim that "microfinance can pay for itself, and must do so if it is to reach very large numbers of poor households" (Brandsma \& Burjorjee 2004: 9). This argument gives the message that unless MFIs charge enough to bear their costs, they will always be restricted by the uncertain and scarce provision of financial support from donors and government. It is also assumed in the statement that microfinance has already achieved satisfactory results for the poor people but there is a need to make it available for more needy people as soon as possible. Morduch (1999) asserted that the interest of investors and donors in microfinance domain indicates a win-win proposition by following the 'ethical banking' principle. This means that the institutions that pursue good banking principles with the likelihood of some return in the form of profit will be able to cover their costs and thus they can serve poor people in a sustainable manner in reducing poverty. Morduch (2000) further explained that the ability of poor people to repay loans indicates that they are getting benefit in the form of profit from the investments they made using microcredit money.

Microfinance is perceived as an outstanding public policy agenda that has received ample attention and success for providing financial support and services to poor people for the improvement of their livelihoods. Microfinance proposals are accepted widely and a number of reputable organisations and banks around the globe sponsored such initiatives (Banerjee \& Duflo 2009). These institutions include: the United Nations, World Bank, NGOs, and several government and non-government charitable organisations. The core aim of supporting this scheme was to promote small scale investments as well as to assist low income people and 
communities by providing them opportunities to generate incomes (Hartarska \& Nadolnyak 2008b; Imai et al. 2010). The success or failure of MFIs depends upon several factors where some institutions failed and ceased already while others are serving million of people.

\section{Microfinance Activities}

\subsection{Microfinance Lending}

Microfinance lending programs are not identical in every country. Generally, there are two types of microfinance lending: group lending and individual lending (Lehner 2009). The fundamental means of group lending scheme are the mutual responsibility for reimbursement of microcredit. The biggest advantage of the group lending program is to motivate the members of the group to screen and monitor each other. This consequently reduces the overall cost of MFIs so that they do not need to conduct extensive screening processes at the individual level. In contrast, the major disadvantage of group lending is that some individuals may take advantage of mutual responsibility and act as free-riders. This problem can be avoided by developing a direct link between the bank and the borrower. This intensifies the flexibility of the microfinance system (Giné et al. 2006). In individual lending, there is a strong need to screen and monitor individuals and as a result the firm will face higher transaction costs. This is the reason that most of the microfinance lenders today lend through group based schemes (Hermes \& Lensink 2007).

\subsection{Microfinance Products and Services}

The products and services of MFIs are not only limited to microfinance credit; instead they also offer other conventional financial services with the name of micro savings and micro insurance. Micro saving refers to an availability of small deposit accounts for poor people for motivating them to save money for future use. Therefore, these deposits many times become more than the outstanding loan amount and consequently act as another source for funding loans (Dhar 2005). On the other hand, micro insurance is offered by MFIs to protect poor people from particular risks and threats by paying consistent insurance premium in proportion to the probability and costs of associated risks (Dhar 2005). Some other services offered by the MFIs include health advice, business development, and education. It is evident that the combination of non-financial and financial services of MFIs has deep contribution in reducing poverty (Zaman 1999).

\subsection{Interest Rates}

The appropriate level of interest rate for microfinance is an ongoing debate since the establishment of Grameen Bank. Generally, MFIs charge high interest rates as compared to the traditional banks. This is because the firms have high operational costs and as a result higher costs per pound lent than the conventional banks (Cull et al. 2009). Kneiding \& Rosenberg (2008) found that the worldwide average interest rate is nearly 35 percent with an exceptional case of 80 percent in Uzbekistan. The interest rate is expected to reduce to some extent in the upcoming years due to an increased level of competition between MFIs. Figure 1 illustrates the entire microfinance process including microfinance stakeholders and activities. 


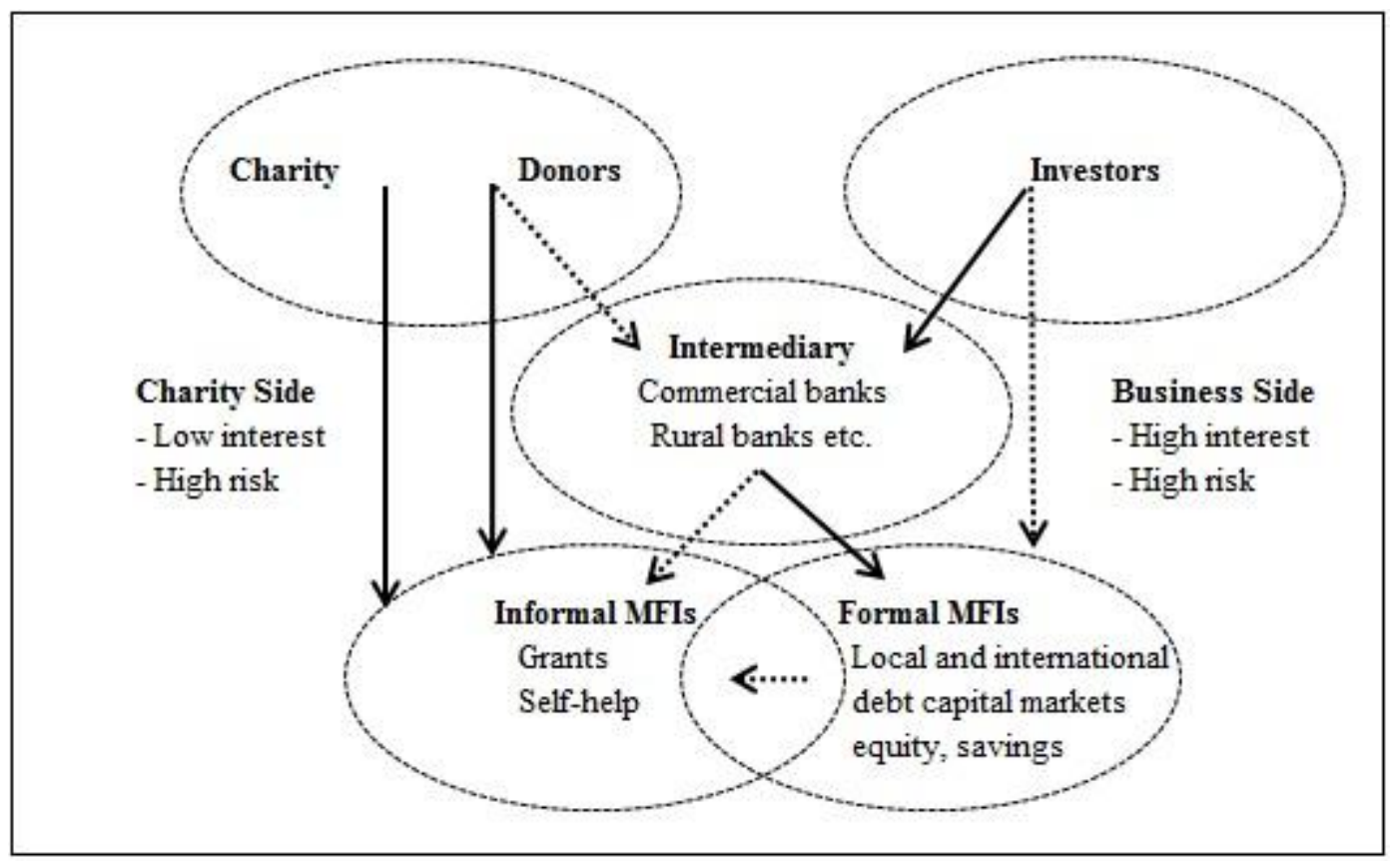

Figure 1. Flow of microfinance financial resources (Srnec et al. 2009, p. 189)

\section{Microfinance in Developing Countries}

The MFIs in developing countries proved that low income people are bankable and small credits have deep impacts on their lives. In particular, the MFIs that started their services in South Asia have expanded rapidly around the world. A survey study reveals that until 2008, MFIs have served nearly 11.8 million poor people in South Asian countries including India, Pakistan, Bangladesh, Sri Lanka, Nepal, and 3.8 million low income people in East Asian countries such as Indonesia, Thailand, Vietnam, China, Philippines (Haq et al. 2008). However, people in South Asia are more reluctant in mobilising saving. The gross portfolio of South Asia is nearly $£ 605$ million as compared to $£ 1,156$ million in East Asia (Haq et al. 2008).

Another proof of the MFIs role in Asian countries is highlighted by the State of Microcredit Summit Campaign Report (2012), where it is stated that MFIs in Asian countries have reached nearly 90 million poor people compared to the low income people in the rest of the world particularly in America, Latin, Africa, Middle East and Caribbean. Moreover, among more than 2000 MFIs in the world, Asian MFIs have achieved highest savings volume and expanded the loans to low income households (Lützenkirche 2012). In fact, the MFIs only in Indonesia and Bangladesh supported over $50 \%$ poor families to improve their livelihoods. Some MFIs operating in developing countries such as Bangladesh, Vietnam, Thailand, and Indonesia have mutually achieved greatest savings mobilisation and loan distribution in terms of the world Gross National Product (GNP).

In South Asia, three MFIs such as Grameen Bank, BRAC, and ASA served around 75 percent poor communities (Haq et al. 2008). Most of their clients were poor women, and the intensity of outreach was also measured in terms of women clients. A recent study reveals that women poor clients in South Asian countries are account for almost 85 percent as compared to other 
counties (Lützenkirche 2012). On the other hand, East Asian MFIs have dominated figures in terms of portfolio loan figures. For example, MFIs in China has the leading portfolio loan figure of $£ 91.5$ billion followed by thrift banks and MFIs in Thailand and Philippines. As compared to the Asian South Eastern countries, the countries in South Asia excel in credit delivery (Haq et al. 2008). However, MFIs in South Asian countries retain compulsory reserves in the form of savings to access loans. Their existing borrowers are three times excess in number and thus retained profit is ten times more as compared to the East Asian countries. For instance, Indonesian MFIs particularly BRI manage more small deposit accounts in contrast to all MFIs in South Asia.

MFIs sustainability also has an important role to intensify their outreach; and they require adequate revenue to achieve the optimum level of sustainability. In contrast to MFIs in South East Asian countries, the performance of South Asian MFIs in terms of lowering down operational costs in not inspiring. In the past decade, Thailand's MFI BAAC has achieved 98\% loan-to-deposit ratio while Bangladeshi MFI the ASA is on top in terms of profitability and performance in South Asian countries (Haq et al. 2008).

\section{Microfinance in Developed Countries}

The financial crisis unexpectedly opened a way for MFIs to offer their services in developed countries which have been adversely affected by the economic downturn. For instance, several MFIs started to seek a licence to open credit unions in the United States after the financial crisis of 2008 (Srnec et al. 2009). It is evident from the commencement of the Grameen America Bank in New York at the end of 2008. The founder of the bank, Muhammad Yunus, asserts that the core aim of obtaining a US credit union licence is to introduce microfinance services at any of the USA states through Grameen America Bank. Grameen America points out that initially the chief revenue source for the institute will be the interest paid by the borrowers on microcredit and ultimately to form a credit union or bank that can also accept bank or saving deposits (Clary 2009). The basic idea behind this philosophy was to encourage MFIs to support low income people by establishing a cooperative type of village banks or credit unions. In this way, the mutual responsibility of MFI owners will be strengthened and consequently the cost of financial services will be reduced.

Another paramount development in the microfinance context in the USA is the provision of guaranteed microcredit to small farmers through the Farm Service Agency (FSA) (Srnec et al. 2009). This facility is available to farmers who cannot borrow loans from the commercial banks. These farmers can use FSA loans for several purposes such as buying of livestock, land, seed, feed, equipment, and supplies. The nature of this type of microfinance is different from those available in the developing countries in terms of economic environment. The FSA service is fully insured and covered with local legislations which significantly reduce the level of risk (USDA 2009).

The microfinance sector in the United Kingdom is slightly different as compared to the USA and other countries. Almost all the British MFIs have common goals to fill gaps in access to credit for economically or socially expelled individuals and enterprises. Some MFIs offer a 
variety of dissimilar products, structures and target groups as compared to other institutions (Carboni et al. 2010). Such institutes are usually known as UK Community Development Finance Institutions (CDFIs). People in the UK are usually not familiar with microfinance as compared to general finance. The MFIs normally emphasise on dissimilar market niches including social enterprises, artistic or cultural firms, starting a business in the villages or deprived area regions, or small credits to formerly jobless females. As some MFIs focus on microfinance credits, the industry altogether offers a variety of products and services to low income people (Brau and Woller 2004). Mary Ellen, the CEO of Women's World Bank in the $\mathrm{UK}$, rejects the concept that microfinance was one of the sources of financial crises. She believes that a great deal equity is still available for microfinance proposals (Johnsson 2009).

\section{Factors Affecting the Growth of Microfinance}

Like financial institutions, MFIs also face difficult times due to internal or external factors. A number of studies identified various causation factors that affect the implementation and growth of microfinance. These factors are thoroughly discussed in this section.

The financial stability is essential for MFIs and requires commercial sources for generating funds (Rai \& Rai 2012). Meehan (2004) argues that MFIs may survive longer if they develop relationships with conventional financial markets at local and international levels for the purpose to generate funds. In addition, to achieve financial stability MFIs should also enhance their efficiency by lowering their operating costs (Adongo \& Stork 2005). Furthermore, attracting investors is also difficult in the microfinance sector because investors typically prefer transparent financial systems that are rarely evident in the microfinance sector. Therefore, they are discouraged by the lack of official recognition and approval of available data and actions of MFIs (Servon 2006).

Another factor is uncontrolled growth which represents the failure of those institutions that experienced quick growth and early success, and then faced crises due to loss of control over microfinance activities. In fact, the primary focus of such MFIs was to expand their branch networks and hire a maximum number of loan officers to achieve growth. But no attention was paid to intensify the efficiency of loan officers to achieve operational productivity (Marulanda et al. 2010). Also in a few cases, the solid portfolio policy itself was besieged by the institutions.

The major benefit of microfinance is to offer small loans to poor people who are in fact trapped in poverty for generations. Therefore, it is not easy to advertise and educate them how small loans can help them to establish their own micro businesses in order to improve their livelihoods. Moreover, international MFIs engage in microfinance activities to clearly communicate their agendas with local poor communities in order to develop trust (Ugur 2006).

Systematic frauds are also evident in several cases of MFIs failure. Many senior officials at the management level misused their positions and powers given to them. They used institutional finance and resources for their personal benefits. In many cases it was found that microfinance loans were granted to friends or relations who were not entitled for those loans 
(Marulanda et al. 2010).

Bureaucracy is another barrier to microfinance particularly in the developing countries. Such problems occur mainly due to political and economic instability where investors are reluctant to invest money and consequently MFIs face difficulties in running microfinance operations smoothly (Lucarelli 2005). Another issue in this domain is associated with the minimum interest rates set by the governments. MFIs find themselves in trouble in achieving sustainability of microfinance with high interest rates imposed by the government (Campion 2002). Similarly, judiciary problems in most of the developing countries enforce MFIs to formulate credit structures under their regulations which also sometimes influence microfinance activities (Servon 2006).

Credit rating attainment can be an expensive option for small MFIs and often considered as deficient in the microfinance sector. Therefore in order to develop trust of people and other stakeholders, it is inherent for MFIs to establish partnerships with commercial banks and giant firms to secure better funding (Ugur 2006). Partnership with commercial banks may also create some problems for MFIs because commercial banks have different approaches to target their customers for financing. Introducing and implementing microfinance strategy can be difficult in terms of understanding low income people and their culture, social values, and traditions etc. For this purpose, commercial banks may need to conduct various training workshops to train their staffs on how to deal with specific clients (Rhyne 2009).

Methodological flaws are also foremost factors that hinder the implementation and growth of MFIs. These issues emerged due to commercial banks when they misjudged microcredit risks and considered that these risks will be treated on later stages and mistakes will be rectified through 'minor adjustments'. Moreover, they left several grateful borrowers behind when they were out of the market and consequently those borrowers had poor credit history with credit bureaus (Marulanda et al. 2010). In some countries, state intervention greatly contributes to the failure of MFIs for informally promoting microfinance activities. This can lead the microfinance market to downfall because of lack of effective monitoring and control for medium and long-term sustainability of microfinance products/services (Marulanda et al. 2010). Some other small but significant factors that hinder the growth of MFI are mentioned by different financial experts and theorists. These factors include: high interest rate, increased competition, client retention, lack of information about the client, client's education level, unregistered lenders, low population density, legislation and regulatory framework, and difficulty in attracting poor clients (Campion 2002; Lucarelli 2005; Servon 2006; Ugur 2006; Marulanda et al. 2010).

\section{Conclusion}

It is found from the review of the existing literature that microfinance is normally perceived as a thriving tool for reducing poverty level but it depends if MFIs can reach real poor people in order to provide them considerable financial support. In addition, it is also perceived that the success of MFIs is based on multiple factors such as interest rate, cost of microfinance, outreach, borrowings, gross loan portfolio, and financial stability. These factors can be managed effectively by adopting good ethical banking principles and by establishing 


\section{MInstitute Macrothink}

relationships with well-recognised international banks, NGOs, and charitable organisations. Although, the awareness of microfinance is more manifest in developing countries due to the high rate of poverty, but there is a strong need to expand microfinance activities at the extensive level in order to support core poor in these countries. On the other hand, the level of microfinance understanding increased in low income people in developed countries particularly after the 2008 financial crisis. Therefore, it is necessary for the developed economies to make available microfinance facilities for needy people. This step will consequently help governments to prevent financial crisis in the future.

The review of a range of studies also reveals many causation factors that hinder the success, growth, and implementation of microfinance systems in developing as well as developed countries. The foremost factors include: lack of financial stability, uncontrolled growth, cultural and value impede, systematic frauds, bureaucratic obstacles, state intervention, methodological defects, and shortage of credit rating agencies. In addition, some other small factors have a weak but significant impact on MFIs in executing microfinance operations. These factors include a high interest rate, increased competition among MFIs, government support, client retention, lack of information about the client, client's education level, unregistered lenders, low population density, legislation and regulatory framework, and difficulty in attracting poor clients.

\section{References}

Adongo, J., \& Stork, C. (2005). Factors Influencing the Financial Sustainability of Selected Microfinance Institutions in Namibia. NEPRU Research Paper 39.

Banerjee, A., \& Duflo, E. (2009). The experimental approach to development economics. Annual Review of Economics, $1, \quad 151-178$. http://dx.doi.org/10.1146/annurev.economics.050708.143235

Brandsma, J., \& Burjorjee, D. (2004). Microfinance in the Arab States: Building inclusive financial sectors. United Nations Capital Development Fund, United States of America

Brau J. C., \& Woller G M. (2004). Microfinance: a Comprehensive Review of the Existing Literature. Journal of Entrepreneurial Finance and Business Ventures, 9(1), 1-26.

Bryman, A. (2008). Social Research Methods (12th ed.). Oxford: Oxford University Press

Campion, A. (2002). Challenges to Microfinance Commercialization. Journal of Microfinance, 4(2), 57-66.

Carboni, B. J., Calderón, M. L., Garrido, S. R., Dayson, K., \& Kickul, J. (2010). Handbook of Microcredit in Europe: Social Inclusion through Microenterprise Development. UK: Edward Elgar Publishing Limited. http://dx.doi.org/10.4337/9781849805308

Clary, T. A. (2009). Banker to the Poor' seeks US credit union license. AFP News, 05 May 2009.

Cull, R., Demirguc-Kunt, A., \& Morduch, J. (2009). Microfinance Meets the Market: Emerging Research in Microfinance Contemporary Studies in Economic and Financial 


\section{Macrothink}

Analysis. Emerald Group Publishing Limited, 92, 1-30.

Dhar, S. N. (2005). Micro-finance for women: necessities, systems, and perceptions. Northern Book Centre.

Fardoust, S., Kim, Y., \& Sepulveda, C. P. (2010). Postcrisis growth and development: A development agenda for the G-20. World Bank Publications. http://dx.doi.org/10.1596/978-0-8213-8518-0

Giné, X., Jakiela P., Dean, K., \& Murdoch, J. (2006). Microfinance Games. World Bank Policy Research Working Paper 3959.

Grameen Bank (2011). Grameen Bank at a Glance. Retrieved from http://www.grameen-info.org/index.php?option=com_content\&task=view\&id=26\&Itemid=1 75

Haq, M., Hoque, M., \& Pathan, S. (2008). Regulation of microfinance institutions in Asia: a comprehensive analysis. International Review of Business Research Papers, 4(4), 421-450.

Hartarska V., \& Nadolnyak, D. (2008b). An impact analysis of microfinance in Bosnia. World Development, 26, 2605-2619. http://dx.doi.org/10.1016/j.worlddev.2008.01.015

Hermes, N., \& Lensink, R. (2007). The Empirics of Microfinance: What do we do now? The Economic Journal, 117, 1-10. http://dx.doi.org/10.1111/j.1468-0297.2007.02013.x

Imai, K. S., Arun, T., \& Annim, S. K. (2010). Microfinance and household poverty reduction: new evidence from India. World Development, 38, 1760-1774. http://dx.doi.org/10.1016/j.worlddev.2010.04.006

Johnsson, E. (2009). Microfinance and the Global Economics Crisis. Time Magazine, 31 May 2009.

Khan, M. A., \& Rahaman, M. A. (2007). Impact of Microfinance on Living Standards, Empowerment and Poverty Alleviation of Poor People: A Case Study on Microfinance in the Chittagong District of Bangladesh. Master Thesis. Umeå School of Business (USBE), Sweden.

King, M. (2012). Tesco and Grameen Bank to provide microfinance in Scotland. The Guardian, 25 October 2012.

Kneiding, C., \& Rosenberg, R. (2008). Variations in Microcredit Interest Rates. Consultative Group to Assist the Poor (CGAP) Brief.

Ledgerwood, J. (1999). Microfinance Handbook: An institutional and financial perspective. World Bank Publications.

Ledgerwood, J., \& White, V. (2006). Transforming Microfinance Institutions: Providing full Financial Services to the Poor. World Bank Publications. http://dx.doi.org/10.1596/978-0-8213-6615-8

Lehner, M. (2009). Group Lending versus Individual Lending in Microfinance. Governance 


\section{Macrothink}

and the Efficiency of Economic Systems. Discussion Paper No. 299, University of Munich.

Lucarelli, B. (2005). Microcredit: A cautionary tale. Journal of Contemporary Asia, 35(1), 78-86. http://dx.doi.org/10.1080/00472330580000051

Lützenkirchen, C. (2012). Microfinance in evolution: an industry between crisis and advancement. Report on Current Issues Global financial market. Germany: Deutsche Bank Research Management.

Marulanda, B., Fajury, L., Paredes, M., \& Gomez, F. (2010). Failures in microfinance: lesson learned." International Association of Microfinance Investors. Retrieved from http://www.calmeadow.com/pdf/failures.pdf

Meehan, J. (2004). Tapping financial markets for microfinance. Working Paper Grameen Foundation USA. Berkeley: University of California.

Momoh, J. (2005). The Role of Micro-financing in Rural Poverty Reduction in Developing Countries. Wismar Discussion Papers, University of Technology Business and Design, Wismar, Germany.

Morduch, J. (1999). The microfinance promise. Journal of Economic Literature, 37, 1569-1614. http://dx.doi.org/10.1257/jel.37.4.1569

Morduch, J. (2000). The Microfinance Schism. Journal of World Development, 28(4), 617-629. http://dx.doi.org/10.1016/S0305-750X(99)00151-5

Murthy, S. N., \& Bhojanna, U. (2009). Business research methods (2nd ed.). India: Excel Books.

Otero, M. (1999). Bringing Development back into Microfinance. Journal of Microfinance, 1, 9-19.

Rai, A. K., \& Rai, S. (2012). Factors Affecting Financial Sustainability of Microfinance Institutions. Journal of Economics and Sustainable Development, 3(6), 1-9.

Rhyne, E. (2009). Microfinance for bankers and investments. India: Tata McGraw-Hill Education

Seibel, H. D. (2005). Does history matter? The old and new World of Microfinance in Europe and Asia. An interdisciplinary workshop, Asia Research Institute, Department of Economics and Department of Sociology, National University of Singapore, pp. 1-2.

Servon, L. J. (2006). Microenterprise Development in the US: Current Challenges and New $\begin{array}{lllll}\text { Directions. Economic Development } & \text { Quarterly, } & 20, & 351 .\end{array}$ http://dx.doi.org/10.1177/0891242406289355

Srnec, K., Vyborna, M., \& Havrland, B. (2009). Microfinance in developing countries and financial crisis. Agricultura tropica et subtropica, 42(4), 187-191.

Steinwand, D. (2001). The Alchemy of Microfinance: The Evolution of the Indonesian People's Credit Bank (BPR) to 1999 and a Contemporary Analysis. Berlin. 


\section{Macrothink}

International Finance and Banking

2014, Vol. 1, No. 1

The State of Microcredit Summit Campaign Report. (2012). The Microcredit Summit Campaign. Retrieved

from

http://www.microcreditsummit.org/state_of_the_campaign_report/

Tulchin, D. (2003). Microfinance's Double Bottom Line: Measuring Social Return for the Microfinance Industry. Seattle, WA: Social Enterprise Associates.

Ugur, Z. (2006). Commercial Banks and Microfinance. College Undergraduate Research Electronic Journal, 1. University of Pennsylvania

USDA. (2009). United States Department of Agricultura, Farm Service Agency. Farm Loan Programs. Retrieved from http://www.fsa.usda.gov/FSA/webapp?area=home\&subject=fmlp\&topic=landing

World Bank. (2005). Agriculture investment sourcebook: agriculture and rural development. World Bank Publications.

Zaman H. (1999). Assessing the Impact of Microcredit on Poverty and Vulnerability in Bangladesh. The World Bank, Policy Research Working Paper. http://dx.doi.org/10.1596/1813-9450-2145

\section{Copyright Disclaimer}

Copyright reserved by the author(s).

This article is an open-access article distributed under the terms and conditions of the Creative Commons Attribution license (http://creativecommons.org/licenses/by/3.0/). 